\title{
Anthropometry, physical activity, and endometrial cancer risk: results from the Netherlands cohort study
}

Citation for published version (APA):

Schouten, L. J., Goldbohm, R. A., \& van den Brandt, P. A. (2006). Anthropometry, physical activity, and endometrial cancer risk: results from the Netherlands cohort study. International Journal of Gynecological Cancer, 16 Suppl 2, 492. https://doi.org/10.1111/j.1525-1438.2006.00676.x

Document status and date:

Published: 01/01/2006

DOI:

10.1111/j.1525-1438.2006.00676.x

Document Version:

Publisher's PDF, also known as Version of record

\section{Please check the document version of this publication:}

- A submitted manuscript is the version of the article upon submission and before peer-review. There can be important differences between the submitted version and the official published version of record.

People interested in the research are advised to contact the author for the final version of the publication, or visit the DOI to the publisher's website.

- The final author version and the galley proof are versions of the publication after peer review.

- The final published version features the final layout of the paper including the volume, issue and page numbers.

Link to publication

\footnotetext{
General rights rights.

- You may freely distribute the URL identifying the publication in the public portal. please follow below link for the End User Agreement:

www.umlib.nl/taverne-license

Take down policy

If you believe that this document breaches copyright please contact us at:

repository@maastrichtuniversity.nl

providing details and we will investigate your claim.
}

Copyright and moral rights for the publications made accessible in the public portal are retained by the authors and/or other copyright owners and it is a condition of accessing publications that users recognise and abide by the legal requirements associated with these

- Users may download and print one copy of any publication from the public portal for the purpose of private study or research.

- You may not further distribute the material or use it for any profit-making activity or commercial gain

If the publication is distributed under the terms of Article $25 \mathrm{fa}$ of the Dutch Copyright Act, indicated by the "Taverne" license above, 
ANTHROPOMETRY, PHYSICAL ACTIVITY, AND ENDOMETRIAL CANCER RISK: RESULTS FROM THE NETHERLANDS COHORT STUDY

L.J. Schouten*, R.A. Goldbohm† \& P.A. van den Brandt*

*Department of Epidemiology, NUTRIM, Maastricht University, MD Maastricht, the Netherlands; and †Business unit Food \& Chemical Risk Analysis, TNO Quality of Life, AJ, Zeist, the Netherlands

Obesity has been identified as a major risk factor for endometrial cancer in many studies. Evidence, however, with respect to height, body mass in adolescence, weight change since adolescence, and physical activity is less extensive ${ }^{(1)}$. In 1986, the Netherlands Cohort Study on Diet and Cancer was initiated. A self-administered questionnaire on dietary habits and other risk factors for cancer was completed by 62,573 women. Data were processed and analyzed using the case-cohort approach, enumerating the cases for the entire cohort, and estimating the person years at risk in the cohort, using a subcohort ${ }^{(2)}$. Follow-up for cancer was established by annual record linkages with the Netherlands Cancer Registry ${ }^{(3)}$. After 9.3 years of follow-up, 226 incident cases of invasive epithelial endometrial cancer and 1739 subcohort members (with an intact uterus at baseline and complete data on anthropometry and confounders) were available for analysis. Rate ratios (RRs) and corresponding 95\% confidence intervals $(95 \% \mathrm{CI})$ were estimated using Cox proportional hazard models. Multivariate RRs were adjusted for age, age at menarche, use of oral contraceptives, age at menopause, parity, cigarette smoking, body mass index (BMI) (in the models for height and physical activity), and physical activity (in the models for BMI).

In multivariate analysis and compared to women with a BMI between 20 and $23 \mathrm{~kg} / \mathrm{m}^{2}$, the RRs of endometrial cancer with BMI up to $25,27,30$, and $>30 \mathrm{~kg} / \mathrm{m}^{2}$ were $1.55,1.93,2.17$, and 4.50 , respectively $(95 \% \mathrm{CI}$ for the top category, $2.62-7.72 ; P$ for trend $<0.01)$. The RR of endometrial cancer with a body mass of $20 \mathrm{~kg} / \mathrm{m}^{2}$ or less at baseline was 1.41 (95\% CI, 0.60-3.30). The risk of women taller than $175 \mathrm{~cm}$ compared to women shorter than $160 \mathrm{~cm}$ was 2.57 (95\% CI, 1.32-4.99) with $P$ trend $=0.09$. BMI at age 20 of years was weakly associated with risk of endometrial cancer. Women with a body mass at age 20 of years of $20 \mathrm{~kg} / \mathrm{m}^{2}$ or less had a RR of 0.67 (95\% CI, 0.45-0.98) compared to women with a BMI between 20 and $23 \mathrm{~kg} / \mathrm{m}^{2}$. A BMI of $25 \mathrm{~kg} / \mathrm{m}^{2}$ and higher at age 20 of years was associated with a RR of 1.33 (95\% CI, 0.77-2.30). Gain in BMI since age 20 of years is positively associated with risk of endometrial cancer. Women with a lower BMI at baseline compared to age 20 of years experienced a decreased risk (RR 0.50; 95\% CI, 0.25-0.97) compared to women with no or only a small increase in body mass (0$<4 \mathrm{~kg} / \mathrm{m}^{2}$ ). For women with an increase of BMI of $8 \mathrm{~kg} / \mathrm{m}^{2}$ or more had a RR of 2.38 (95\% CI, 1.48-3.84) compared to the same reference category. Higher physical activity was associated with a decreased risk of endometrial cancer. Compared to women who spent less than 30 min per day on recreational physical activity, the RRs of endometrial cancer for recreational activity up to 60,90 , and $>90$ min per day were $0.81,0.59$, and 0.54 (95\% CI for the top category, $0.34-0.85$; $P$ trend, 0.002). Daily biking and walking explained most of the observed effect of physical activity.

Height at baseline and BMI at age 20 of years are possibly related to an increased risk of endometrial cancer. Gain in body mass since age 20 and BMI at baseline are strongly associated with an increased risk, and physical activity is associated with a decreased risk of endometrial cancer ${ }^{(4)}$.

\section{References}

1 Vainio H, Bianchini F. Weight control and physical activity. IARC Handbooks of Cancer Prevention. Vol. 6. Lyon, France: IARC Press, 2002.

2 van den Brandt PA, Goldbohm RA, van 't Veer P et al. A large-scale prospective cohort study on diet and cancer in The Netherlands. J Clin Epidemiol 1990:43:285-95.

3 Van den Brandt PA, Schouten LJ, Goldbohm RA et al. Development of a record linkage protocol for use in the Dutch Cancer Registry for Epidemiological Research. Int J Epidemiol 1990;19: 553-8.

4 Schouten LJ, Goldbohm RA., van den Brandt PA. Anthropometry, physical activity, and endometrial cancer risk: results from the Netherlands Cohort Study. J Natl Cancer Inst 2004;96:1635-8.
Address correspondence and reprint requests to: Leo J. Schouten, $\mathrm{MD}, \mathrm{PhD}$, Department of Epidemiology, Nutrition and Toxicology Research Institute Maastricht (NUTRIM), Maastricht University, P.O. Box 616, 6200 MD Maastricht, the Netherlands. Email: lj.schouten@ epid.unimaas.nl
(C) 2006, Copyright the Authors Journal compilation (C) 2006, IGCS 